ORIGINAL ARTICLE

\title{
Anuran diversity in urban and rural zones of the Itacoatiara municipality, central Amazonia, Brazil
}

\author{
Marcelo MENIN ${ }^{1 *}$, Rafaela Fernanda Batista FERREIRA², Izomar Barbosa MELO², Marcelo GORDO ${ }^{1}$, \\ Gustavo Yomar HATTORI ${ }^{2}$, Bruno Sampaio SANT'ANNA² \\ Universidade Federal do Amazonas, Instituto de Ciências Biológicas, Departamento de Biologia and Programa de Pós-Graduação em Zoologia, Av. General Rodrigo \\ Otávio Jordão Ramos, 6200, 69077-000, Manaus, AM, Brasil. \\ 2 Universidade Federal do Amazonas, Instituto de Ciências Exatas e Tecnologia (ICET), Rua Nossa Senhora do Rosário, 3863, Tiradentes, 69103-128, Itacoatiara, AM, Brasil. \\ * Corresponding author: menin@ufam.edu.br
}

\begin{abstract}
Few studies in the Amazon region have evaluated anuran diversity in urban forest fragments or in areas with differing degrees of anthropogenic impact. We determined the composition and abundance of the anurofauna in urban and rural sites within the municipality of Itacoatiara in central Amazonia, Brazil. Specimens were sampled from January 2012 to May 2013 in 10 urban sites and five rural sites. A total of 1,538 anurans (930 in rural sites and 608 in urban sites) were recorded, belonging to 29 species in five families. Species richness was higher in rural sites, with 10 exclusive species. All species found in urban sites were also found in rural sites, however, species abundance varied considerably between the habitats. Sampling- and individualbased rarefaction curves showed a tendency toward stabilization of species richness only in the urban sites. We concluded that the anuran assemblages in the urban sites are depauperate due to the absence of many species associated to pristine terra firme or várzea and igapó forests. Habitat loss and quality degradation in urban landscapes are the main factors threatening amphibian diversity. The anuran assemblages in our study areas were similar to those recorded in other Amazonian habitats. Conservation measures involving anurans in this region should consider the preservation of habitat mosaics, including both pristine terra firme, várzea and igapó forests.
\end{abstract}

KEYWORDS: floodplain forests, unflooded forest, rarefaction curves, species composition, time-constrained searches

\section{Diversidade de anuros nas zonas urbana e rural de Itacoatiara, Amazônia central, Brasil}

\section{RESUMO}

Poucos estudos avaliaram a diversidade de anuros em fragmentos florestais urbanos ou em áreas com diferentes graus de impacto antrópico na Amazônia. Neste estudo foi determinada a composiçâo e abundância de anuros em áreas urbanas e rurais no município de Itacoatiara, na Amazônia central, Brasil. Anuros foram amostrados entre janeiro de 2012 e maio de 2013 em 10 locais na área urbana e cinco na área rural. Um total de 1.538 indivíduos (930 na área rural e 608 na área urbana) foram registrados, compreendendo 29 espécies e cinco famílias. A área rural apresentou maior riqueza de espécies, com 10 espécies exclusivas. Todas as espécies identificadas na área urbana também foram encontradas na área rural, mas a abundância das espécies entre ambas áreas variou consideravelmente. Curvas de rarefação por amostragem e por número de indivíduos tenderam à estabilização na riqueza de espécies somente na área urbana. Concluímos que a comunidade de anuros na área urbana está empobrecida devido à ausência de muitas espécies associadas à ambientes inalterados de florestas de terra firme, várzea e igapó. A degradação da qualidade e a perda de habitat nas paisagens urbanas são os principais fatores que ameaçam a diversidade de anfíbios. A comunidade de anuros registrada neste estudo foi similar às de outros habitats na Amazônia. Medidas de conservação envolvendo anuros nesta região devem considerar a preservação de um mosaico de habitats que inclua áreas naturais de floresta de terra firme, várzea e igapó.

PALAVRAS-CHAVE: composição de espécies, curvas de rarefação, busca com tempo limitado, florestas de terra-firme, várzea 


\section{INTRODUCTION}

Urban growth ranks as a serious threat to animal biodiversity, affecting the richness and abundance of many species (Delis et al. 1996). Due to the increase of human population and migration, it is expected that there will be nearly 2 billion new urban residents in the world by 2030. However, the consequences of current and future urbanization for the biodiversity conservation are poorly known (McDonald et al. 2008). Species composition shows pronounced changes along the urban-rural gradient, with non-native species becoming more common closer to the urban cores (McKinney 2002).

Brazil is home to an average $13 \%$ of the world's biodiversity (Lewinsohn and Prado 2005), including the greatest amphibian richness, with 1,080 documented species (Segalla $e t$ al. 2016). Part of this diversity is found in the Amazon region, the largest tropical forest on the planet, most of which remains relatively well preserved. Yet phytophysiognomies in the Amazon have undergone extensive changes in recent decades due to anthropogenic activities and their impact on habitat degradation (Fearnside 2005). In the Brazilian Amazon, 332 amphibian species, including 309 anurans have been recorded (Hoogmoed and Galatti 2017), however, these numbers may well be underestimates due to inconsistencies in the taxonomy of various amphibian groups (Avila-Pires et al. 2007), and cryptic diversity (e.g. Funk et al. 2012).

Amphibians are sensitive to environmental degradation (Navas and Otani 2007), and some 32\% of amphibian species worldwide are known to be either extinct or under threat of extinction (Stuart et al. 2008), including 41 anuran species in Brazil (MMA 2014). Decreased habitat quality (Hamer and McDonnell 2008), habitat fragmentation (Tocher et al. 2001), and microhabitat loss in urban areas are the primary causes of biodiversity loss in general, and decline of amphibian populations in particular (Silvano and Segalla 2005). Diseases, climate change, and environmental contamination also have been studied as potential causes for the decline and extinction of amphibian populations (e.g. Beebee and Griffiths 2005).

Although the number of studies of anuran communities in the Brazilian Amazon has increased in recent years, most were conducted in pristine areas (e.g. Neckel-Oliveira and Gordo 2004; Pantoja and Fraga 2012; Waldez et al. 2013), or in forest fragments in rural zones (e.g. Tocher 1998; Tocher et al. 2001). Few studies have analyzed Amazonian anuran diversity in urban forest fragments (Knispel and Barros 2009; Tsuji-Nishikido and Menin 2011; Venâncio et al. 2014), or compared anuran diversity in pristine forests and areas with varying degrees of anthropogenic impact (Estupinán and Galatti 1999; Bernarde and Macedo 2008; Silva and Silva 2010). A decrease in anuran species richness and composition has been reported in highlyimpacted areas, due to changes in rainfall, temperature and humidity that resulted in reduced availability of breeding sites (Estupiñán and Galatti 1999; Bernarde and Macedo 2008). On the other hand, amphibian species that are habitat generalists can increase their chances of survival in urban and suburban landscapes by using artificial water bodies for reproduction (Hamer and McDonnell 2008).

The region of the municipality of Itacoatiara (Amazonas state), in central Amazonia, is composed of a mosaic of seasonal várzea and igapó (floodplain forests) and terra firme (unflooded) forests (Hess et al. 2003). Urbanized areas within the municipality are relatively small, and surrounded by rural areas, which leads to a low degree of habitat disturbance and provides an interesting model system in which to study the effects of the urban-rural gradient on species diversity and composition.

Therefore, the aim of this study was to investigate the differences between anuran assemblages of urban and rural landscapes in the municipality. We analyzed the composition, abundance, dominance, and constancy of nocturnal anuran species. We hypothesized that the species assemblages in urban sites are composed of species primarily from open habitats, while assemblages from rural sites are composed mainly of species from different types of forests.

\section{MATERIAL AND METHODS}

\section{Study areas}

The study was carried out in sites located in rural and urban zones in the municipality of Itacoatiara, Amazonas state, Brazil, located on the northern margin of the middle Amazonas River, in central Amazonia (Figure 1), and covering an area of 8,892 $\mathrm{km}^{2}$ (SEPLANCTI 2015). The climate is Am (Köppen-Geiger system, tropical monsoon, without a dry season) (Peel et al. 2007), and the mean annual rainfall and temperature are 1,885 $\mathrm{mm}$ and $27^{\circ} \mathrm{C}$, respectively. The rainy season typically occurs from November to May, with the heaviest rainfall from March through May (Marques Filho et al. 1981). The floodplain areas are called várzea and igapó (Junk 2000), and the unflooded areas are covered by terra firme forest.

We sampled 15 sites, 10 located in the urban zone and five in the rural zone of the municipality (Table 1). Urban sites were characterized by high density of houses and roads, following Oda et al. (2017). In the urban environment we concentrated the sampling effort on abandoned terrains containing water bodies (streams and ponds) that are filled during the rainy season and known to be used by frogs for reproduction. The vegetation in these areas consisted mostly of shrubs, grasses and sparse trees (Table 1). All sampling sites were in close proximity to human residences. Rural sites were located outside of, or along the perimeter of, the urban sites and were characterized by the presence of agricultural activity, fish- and cattle-farms, small plantations and forest fragments. The rural sites were composed mostly of várzea and igapó forests, which are flooded from December to August, and terra firme forest. The vegetation consisted of shrubs, forest with a fairly dense canopy, and an 

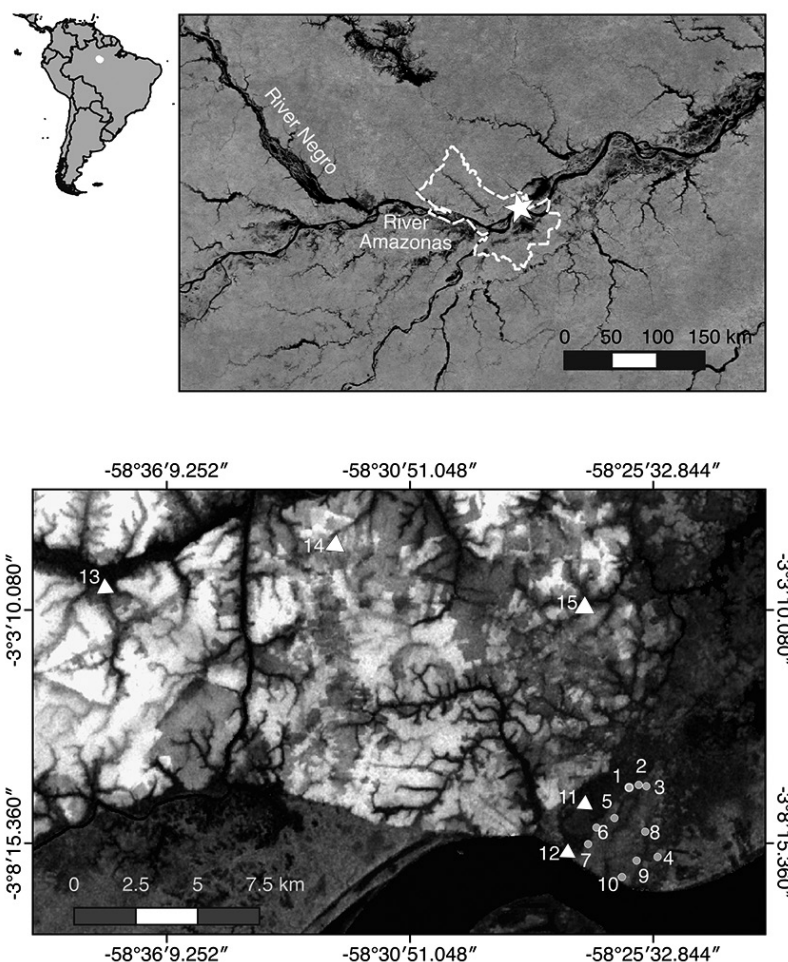

Figure 1. Geographical location of the sampling sites, Itacoatiara municipality, Amazonas State, Brazil. Dots = urban sampling sites (1 to 10). Triangles $=$ rural sampling sites (11 to 15). Site numbers correspond with Table 1. understory with low and fragmented light penetration. All sampling sites, with the exception of one site in the várzea habitat, contained permanent and temporary water bodies such as puddles, ponds, streams or small lakes.

\section{Sampling methods and species identification}

Nocturnal anuran assemblages were surveyed through time-constrained searches (Scott 1994) on the ground, vegetation and along the margins of ponds and streams. Samplings were conducted from January to April 2012 in the urban sites, and from December 2012 to May 2013 in the rural sites, using three person-hours, between 19:00 and 22:00 h, per site. The sampling effort employed in each site is expressed as person-hours. Each urban site was visited twice, totaling 180 person-hours ( 3 people $\times 3$ hours $\times 10$ sites $\times 2$ samplings). Rural sites were visited four times, also totaling 180 person-hours $(3$ people $\times 3$ hours $\times 5$ sites $\times 4$ samplings). All collected specimens were transported to the laboratory for identification. Species were identified based on their morphology using Rodríguez and Duellman (1994), Duellman (2005), Lima et al. (2012), and taxonomic expertise of the team. Nomenclature in this study follows Amphibian Species of the World (Frost 2018). Voucher specimens of each species were anesthetized and killed using 5\% lidocaine chlorhydrate, preserved in $10 \%$ formalin, later transferred to $70 \%$ ethanol, and deposited in the Amphibians Section of the

Table 1. Identification, geographical coordinates and habitat characterization of each sampling site for anuran diversity and abundance, Itacoatiara municipality, Amazonas State, Brazil.

\begin{tabular}{|c|c|c|c|}
\hline Site nr. & Site name & Coordinates & Site characteristics \\
\hline \multicolumn{4}{|c|}{ URBAN SITES } \\
\hline 1 & Bairro Jardim Adriana & $03^{\circ} 06^{\prime} 59.1^{\prime \prime S}, 58^{\circ} 25^{\prime} 51.6^{\prime \prime} \mathrm{W}$ & Abandoned terrain with shrubs, grasses, trees and stream \\
\hline 2 & Bairro Jardim Amanda & $03^{\circ} 06^{\prime} 59.1^{\prime \prime S}, 58^{\circ} 25^{\prime} 51.8^{\prime \prime} \mathrm{W}$ & Abandoned terrain with shrubs, grasses and stream \\
\hline 3 & Bairro da Paz & $03^{\circ} 07^{\prime} 00.8^{\prime \prime S}, 58^{\circ} 25^{\prime} 41.7^{\prime \prime} \mathrm{W}$ & Abandoned terrain with shrubs, grasses and stream \\
\hline 4 & Bairro Mamud Amed & $03^{\circ} 08^{\prime} 33.3^{\prime \prime} \mathrm{S}, 58^{\circ} 25^{\prime} 27.1^{\prime \prime} \mathrm{W}$ & Abandoned terrain with shrubs, grasses and stream \\
\hline 5 & Bairro Novo Horizonte & $03^{\circ} 07^{\prime} 42.4^{\prime \prime} \mathrm{S}, 58^{\circ} 26^{\prime} 23.4^{\prime \prime} \mathrm{W}$ & Abandoned terrain with shrubs, grasses and stream \\
\hline 6 & Barreira & $03^{\circ} 07^{\prime} 54.9^{\prime \prime} \mathrm{S}, 58^{\circ} 26^{\prime} 47.1^{\prime \prime} \mathrm{W}$ & Abandoned terrain with shrubs, grasses and stream \\
\hline 7 & Bairro Pedreiras & $03^{\circ} 08^{\prime} 16.5^{\prime \prime} \mathrm{S}, 58^{\circ} 26^{\prime} 58.0^{\prime \prime} \mathrm{W}$ & Terrain with shrubs, grasses, trees and stream in a particular property \\
\hline 8 & Bairro Tiradentes & $03^{\circ} 08^{\prime} 00.3^{\prime \prime} \mathrm{S}, 58^{\circ} 25^{\prime} 43.2^{\prime \prime} \mathrm{W}$ & Abandoned terrain with shrubs, grasses, trees and stream \\
\hline 9 & Bairro São Jorge & $03^{\circ} 08^{\prime} 38.1^{\prime \prime} \mathrm{S}, 58^{\circ} 25^{\prime} 54.4^{\prime \prime} \mathrm{W}$ & Terrain with shrubs, grasses, trees and stream \\
\hline 10 & Bairro Jauary & $03^{\circ} 08^{\prime} 59.6^{\prime \prime} \mathrm{S}, 58^{\circ} 26^{\prime} 13.6^{\prime \prime} \mathrm{W}$ & Abandoned terrain with shrubs, grasses, trees and rainwater ponds \\
\hline \multicolumn{4}{|c|}{ RURAL SITES } \\
\hline 11 & Aeroporto & $03^{\circ} 07^{\prime} 23.3^{\prime \prime} \mathrm{S}, 58^{\circ} 27^{\prime} 00.1^{\prime \prime} \mathrm{W}$ & Várzea forest and stream \\
\hline 12 & Centenário & $03^{\circ} 08^{\prime} 24.5^{\prime \prime S}, 58^{\circ} 27^{\prime} 24.6^{\prime \prime} \mathrm{W}$ & Igapó forest and areas with shrubs, grasses, tress and stream \\
\hline 13 & Caru & $03^{\circ} 02^{\prime} 38.5^{\prime \prime} \mathrm{S}, 58^{\circ} 37^{\prime} 31.6^{\prime \prime} \mathrm{W}$ & Várzea forest and area with shrubs, grasses, trees and stream \\
\hline 14 & Litiara & $03^{\circ} 01^{\prime} 42.8^{\prime \prime} \mathrm{S}, 58^{\circ} 32^{\prime} 29.6^{\prime \prime} \mathrm{W}$ & $\begin{array}{l}\text { Shrubs, grasses, artificial } \\
\text { ponds and terra firme forest around }\end{array}$ \\
\hline 15 & Comunidade da Penha & $03^{\circ} 03^{\prime} 05.7^{\prime \prime S}, 58^{\circ} 27^{\prime} 02.7^{\prime \prime} \mathrm{W}$ & Várzea forest and areas with shrubs, grasses and stream \\
\hline
\end{tabular}


Paulo Bürhnheim Zoological Collection of the Universidade Federal do Amazonas - (CZPB-AA) (Supplementary Material, Appendix S1). Tissue samples were not collected. The remaining individuals were released in nearby areas to avoid recapture in subsequent samplings. The collection permit was granted by the Instituto Chico Mendes de Conservação da Biodiversidade / ICMBio (\# 32557-1).

\section{Data analysis}

For both urban and rural sites, sample- and individual-based rarefaction curves (sensu Gotelli and Colwell 2001) were obtained from 1,000 randomizations using the $S($ est ) analytical index (Colwell et al. 2012) in the EstimateS 9 program (Colwell 2013). This method is appropriate for estimating species richness and for comparing data sets containing different numbers of individuals (Gotelli and Colwell 2001).

Species dominance and diversity were determined using the Berger-Parker dominance index (d) and the Shannon-Wiener diversity index (H'; Krebs 1999), respectively. All analyses were performed using PAST software (Hammer et al. 2001). The frequency of each species was calculated using the constancy index (Dajoz 1973): $C=$ pix 100/P, where $C$ is the constancy value for the species, $p i$ is the number of samples in which species $i$ was found, and $P$ is the total number of samples. According to this index, if $C \geq 50 \%$ the species is considered "constant", if $25 \% \leq C \leq 50 \%$ the species is "accessory" and if $C \leq 25 \%$ the species is "accidental". Ordinations of species composition were made for rural and urban sites via multivariate analysis based on a non-metric multidimensional scaling (NMDS), and using Primer 6.0 software. Ordination of quantitative (abundance) and qualitative (presence/absence) data were estimated with the Bray-Curtis dissimilarity index on site-standardized (proportion of each species in each site) and square-root transformed data, and the Jaccard index, respectively. In the NMDS the stress value reflects how well the ordination summarizes the observed distances between the samples, and values lower than $20 \%$ can be ecologically interpretable (Hu et al. 2015). In addition, we used one-way analysis of similarity (ANOSIM) tests to assess differences in anuran composition in rural and urban sites based on quantitative and qualitative data.

\section{RESULTS}

We recorded 1,538 specimens (930 in the rural sites and 608 in the urban sites), belonging to 29 species from five families (Table 2). Hylidae was the family with the highest number of species (18) representing $62 \%$ of the total number of sampled species, followed by Leptodactylidae (7;24\%), Bufonidae (2; $8 \%$ ), and Microhylidae and Pipidae (1 species each; 3\%).

Twenty-nine species were found in the rural sites (Table 2), varying from nine to 15 species (Figure 2A), and from 74 to 393 individuals (Figure 2B). Ten species were recorded exclusively in rural sites (Boana boans, Boana aff. cinerascens, Boana cf. fasciata, Boana geographica, Boana wavrini, Osteocephalus taurinus, Scinax boesemani, Scinax garbei, Leptodactylus longirostris, and Leptodactylus pentadactylus). Dendropsophus walfordi was the most abundant species, representing $17 \%$ of all specimens collected in the rural sites, followed by B. geographica (13\%) and Leptodactylus podicipinus (13\%). Nineteen species were found in the urban sites (Table 2), varying from six to 11 species (Figure 2A), and from 19 to 138 individuals (Figure 2B). No species was exclusive to urban sites. Rhinella major was the most abundant species, representing $27 \%$ of all specimens collected at urban sites.

Table 2. Number of individuals and constancy of occurrence per species of anurans recorded in rural and urban sites, Itacoatiara municipality, Amazonas State, Brazil. Ace $=$ Accessory; Acc $=$ Accidental; Cons $=$ Constant .

\begin{tabular}{|c|c|c|c|c|}
\hline \multirow{2}{*}{ Family / Species } & \multicolumn{2}{|c|}{$\begin{array}{l}\text { Number of } \\
\text { individuals }\end{array}$} & \multicolumn{2}{|c|}{$\begin{array}{l}\text { Constancy of } \\
\text { occurrence }\end{array}$} \\
\hline & $\begin{array}{l}\text { Rural } \\
\text { sites }\end{array}$ & $\begin{array}{l}\text { Urban } \\
\text { sites }\end{array}$ & $\begin{array}{l}\text { Rural } \\
\text { sites }\end{array}$ & $\begin{array}{c}\text { Urban } \\
\text { sites }\end{array}$ \\
\hline \multicolumn{5}{|l|}{ BUFONIDAE } \\
\hline Rhinella major (Spix, 1824) & 32 & 165 & Ace & Cons \\
\hline Rhinella marina (Linnaeus, 1758) & 18 & 17 & Ace & Acc \\
\hline \multicolumn{5}{|l|}{ HYLIDAE } \\
\hline Boana boans (Linnaeus, 1758) & 4 & 0 & AcC & - \\
\hline Boana aff. cinerascens (Spix, 1824) & 6 & 0 & Acc & - \\
\hline Boana cf. fasciata (Günther, 1858) & 28 & 0 & Acc & - \\
\hline Boana geographica (Spix, 1824) & 125 & 0 & Cons & - \\
\hline Boana lanciformis (Cope, 1871) & 1 & 5 & Acc & Acc \\
\hline Boana punctata (Schneider, 1799) & 1 & 48 & Acc & Ace \\
\hline Boana raniceps (Cope, 1862) & 54 & 10 & Ace & Ace \\
\hline Boana wavrini (Parker, 1936) & 8 & 0 & Acc & - \\
\hline Dendropsophus leucophyllatus (Beireis, 1783) & 4 & 81 & Acc & Acc \\
\hline Dendropsophus rossalleni (Goin, 1959) & 3 & 3 & Acc & Acc \\
\hline Dendropsophus walfordi (Bokermann, 1962) & 155 & 32 & Cons & Cons \\
\hline Lysapsus bolivianus Gallardo, 1961 & 96 & 3 & Ace & Acc \\
\hline Osteocephalus taurinus Steindachner, 1862 & 1 & 0 & Acc & - \\
\hline Scinax boesemani (Goin, 1966) & 67 & 0 & Acc & - \\
\hline Scinax garbei (Miranda-Ribeiro, 1926) & 1 & 0 & Acc & - \\
\hline Scinax ruber (Laurenti, 1768) & 59 & 25 & Cons & Ace \\
\hline Sphaenorhynchus dorisae (Goin, 1957) & 1 & 3 & Acc & Acc \\
\hline Trachycephalus typhonius (Linnaeus, 1758) & 1 & 18 & Acc & Ace \\
\hline \multicolumn{5}{|l|}{ LEPTODACTYLIDAE } \\
\hline Adenomera hylaedactyla (Cope, 1868) & 1 & 8 & Acc & Acc \\
\hline Leptodactylus fuscus (Schneider, 1799) & 13 & 49 & Acc & Cons \\
\hline Leptodactylus longirostris Boulenger, 1882 & 13 & 0 & Ace & - \\
\hline $\begin{array}{l}\text { Leptodactylus macrosternum Miranda- } \\
\text { Ribeiro, } 1926\end{array}$ & 77 & 36 & Cons & Cons \\
\hline Leptodacty/us pentadactylus (Laurenti, 1768) & 4 & 0 & Acc & - \\
\hline Leptodactylus petersii (Steindachner, 1864) & 26 & 8 & Ace & Acc \\
\hline Leptodactylus podicipinus (Cope, 1862) & 120 & 77 & Cons & Cons \\
\hline \multicolumn{5}{|l|}{ MICROHYLIDAE } \\
\hline Elachistocleis helianneae Caramaschi, 2010 & 10 & 16 & Acc & Acc \\
\hline \multicolumn{5}{|l|}{ PIPIDAE } \\
\hline Pipa pipa (Linnaeus, 1758) & 1 & 4 & AcC & Acc \\
\hline
\end{tabular}


We observed a great difference in the number of individuals between the species when comparing sampling sites. Rhinella major, Boana punctata, Dendropsophus leucophyllatus, Trachycephalus typhonius, and Leptodactylus fuscus were more abundant in urban sites, while Boana raniceps, D. walfordi, Lysapsus bolivianus, Scinax ruber, Leptodactylus macrosternum, Leptodactylus petersii, and L. podicipinus were more abundant in rural sites (Table 2).

Sampling-and individual-based rarefaction curves from rural sites showed no tendency toward stabilization (Figures $3 \mathrm{~A}$ and $\mathrm{B})$. On the other hand, the sampling effort in the urban sites was such that the rarefaction curves showed a weak tendency to report more species in this treatment (Figures $3 \mathrm{C}$ and D). Rural sites had higher species diversity $\left(H^{\prime}=2.59\right.$ vs $\left.H^{\prime}=2.37\right)$, while the urban sites showed a higher dominance index $(\mathrm{d}=0.27 \mathrm{vs} \mathrm{d}=0.16)$. The constancy index showed high numbers of accidental species in both rural and urban sites, $62 \%$ and $53 \%$, respectively (Table 2).

Ordination of the anuran assemblage composition based on quantitative data (Stress $=0.17$ ) resulted in a cluster with most urban sites partially segregated from the rural sites (Figure 4A). Ordination based on qualitative data (Stress = $0.19)$ resulted in a cluster with most urban and rural sites close to each other (Figure 4B). A one-way Anosim test using the treatment as a factor was significant for quantitative data $(\mathrm{R}$ global $=0.26 ; \mathrm{p}=0.04)$, but was non-significant for qualitative data $(\mathrm{R}$ global $=0.14 ; \mathrm{p}=0.15)$. Direct ordination based on anuran species presence/absence data for all sampling sites indicated a clear division between urban and rural sites due the presence of exclusive species in rural sites (Figure 5). However, most species occurred in both rural and urban sites (Figure 5).
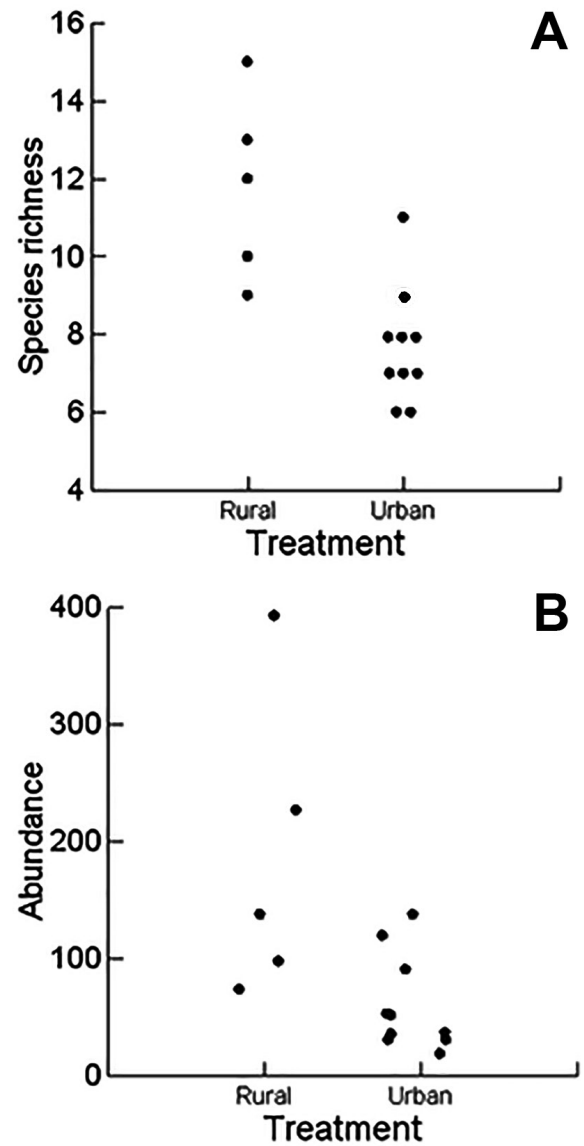

Figure 2. Number of species (A) and abundance of individuals (B) of nocturnal anurans in 10 urban and five rural sampling sites, Itacoatiara municipality, Amazonas State, Brazil.
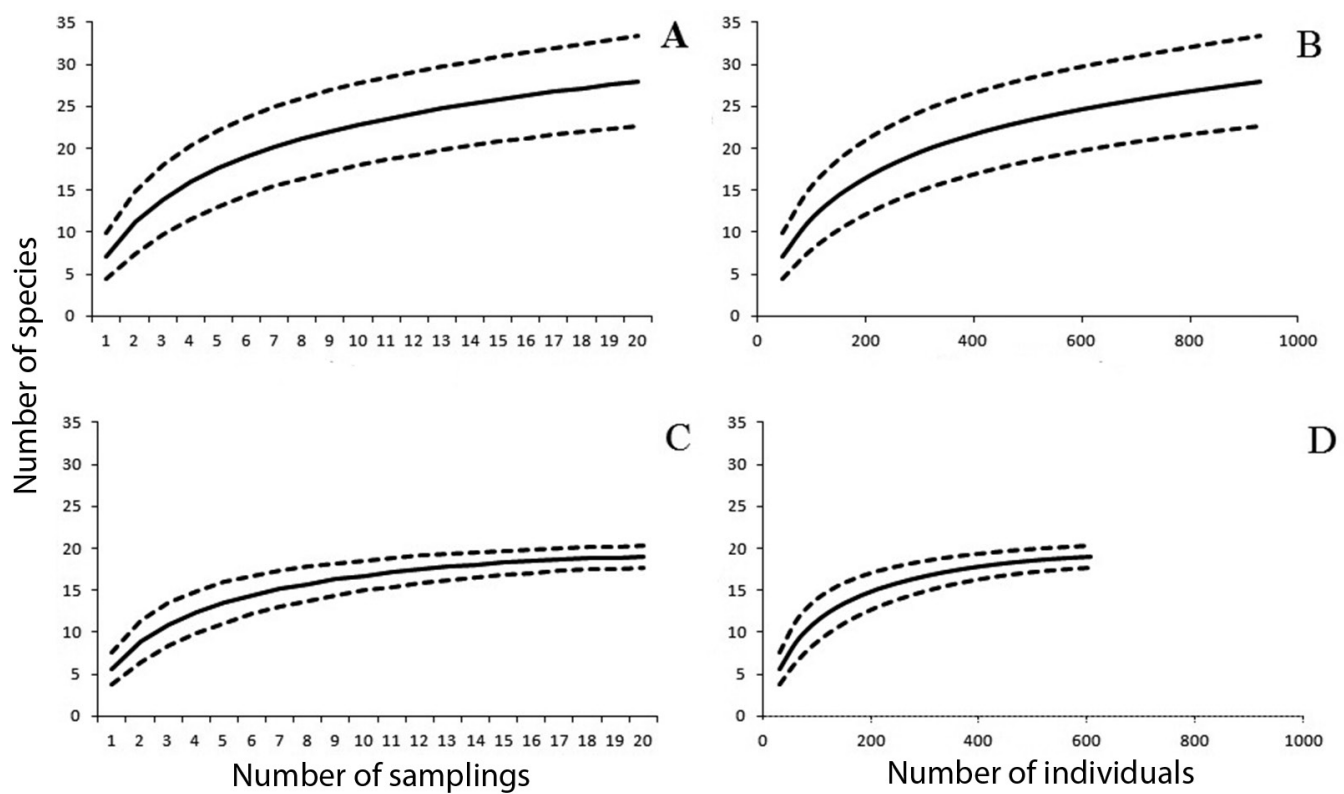

C

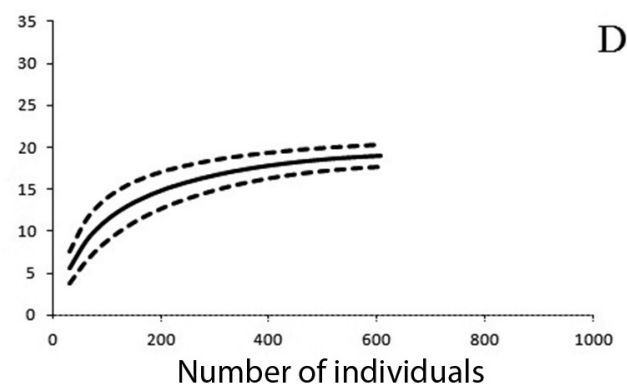

Figure 3. Rarefaction curves based on the number of samples ( $A$ and $C$ ), and the number of individuals ( $B$ and $D$ ) of nocturnal anuran species, Itacoatiara municipality, Amazonas State, Brazil. A and B = rural sampling sites; $C$ and $D=$ urban sampling sites. The continuous line represents the average calculated via 1,000 randomizations and the dashed lines represent the upper and lower $95 \%$ confidence intervals. 

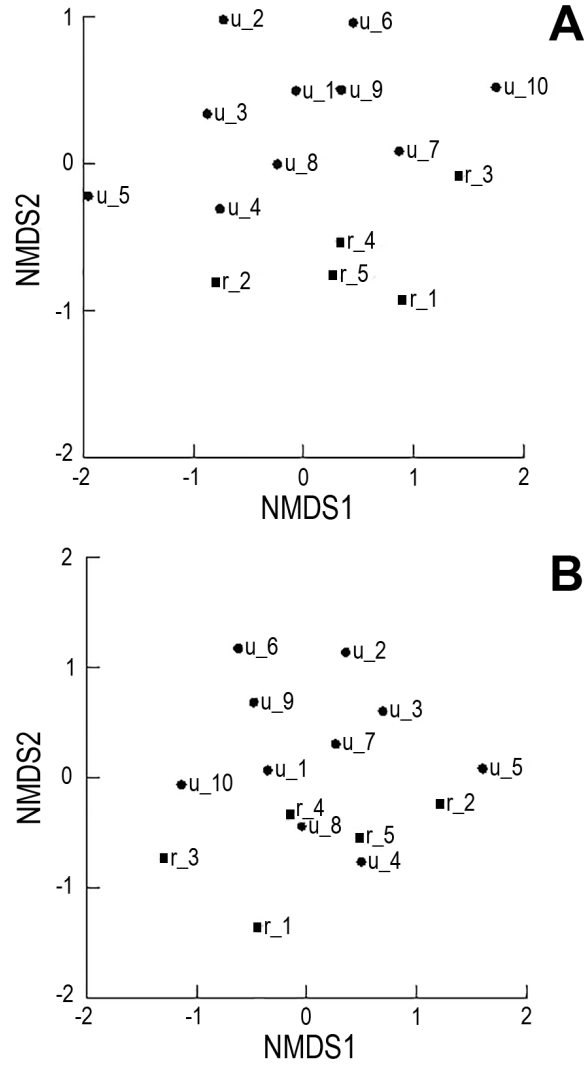

Figure 4. Non-metric multidimensional scaling (NMDS) based on abundance (A) and presence/absence (B) of anuran species from urban and rural sampling sites, Itacoatiara municipality, Amazonas State, Brazil. Urban ( $u$ ) and rural (r) site numbers correspond with Table 1.

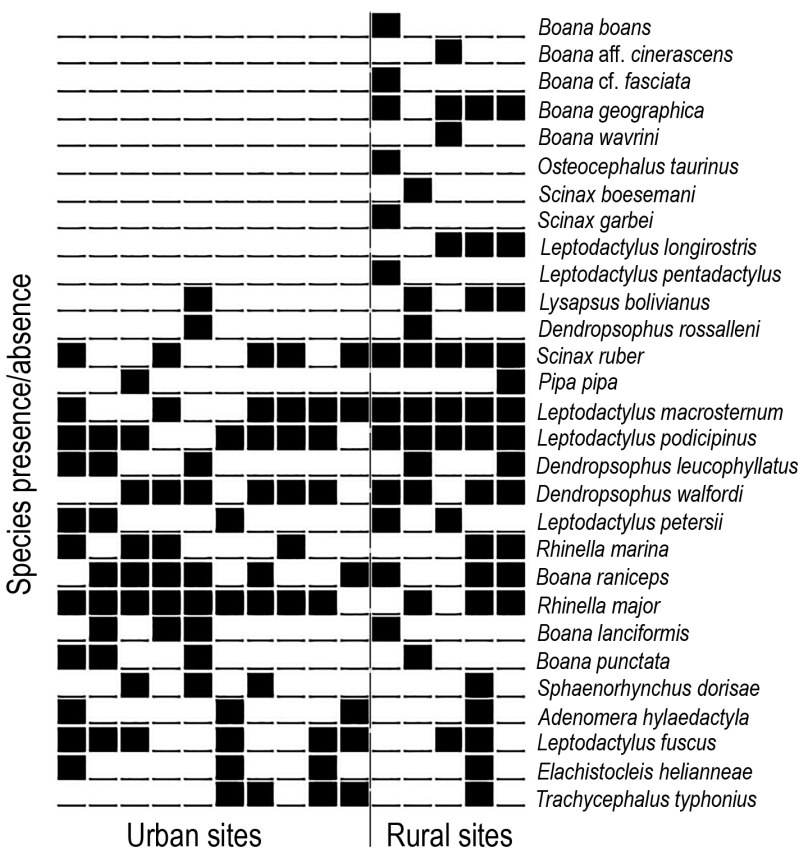

Figure 5. Direct ordination of presence and absence data of anuran species for 10 urban and five rural sampling sites, Itacoatiara municipality, Amazonas State, Brazil.

\section{DISCUSSION}

Our results showed that anuran assemblages differed between urban and rural sites in the Itacoatiara municipality. As expected, anuran diversity was higher in rural sites (29 species) than in urban sites (19 species), probably due to that (a) rural sampling sites were located in less anthropically-impacted areas than urban sites, and included a habitat mosaic of várzea, igapó and terra firme forests, and (b) urbanization may have decreased species richness and abundance due to habitat modification caused by anthropogenic activities (Pillsbury and Miller 2008) such as the reduction of vegetation heterogeneity (Oda et al. 2017). Additionally, species composition in urban sites was a subset of the species found in pristine areas or zones with lower degree of habitat disturbance.

Habitat loss and forest fragmentation are the primary and most obvious anthropic effects impacting biodiversity loss around the world (Cushman 2006; Verdade et al. 2012). These effects have a negative impact on amphibian fauna, including reduction of species richness and abundance and alteration of species distribution in forest fragments (Fahrig 2003). Although we could assess only the presentday pattern of species composition in the urban sites of the Itacoatiara municipality, the conversion of forest into open areas has probably been the main mechanism responsible for the replacement of forest species by those that appear welladapted to open habitats (Bitar et al. 2015). Similar results were reported in the eastern Amazon, where species richness decreased with increasing intensity of human impact, varying from 37 species in terra firme forests to 19 species in urban sites (Estupiñán and Galatti 1999). Likewise, in an experiment involving forest fragmentation in central Amazonia, Tocher $e t$ al. (2001) observed a decrease in the total number of species proportional to the increase of disturbance level. In the current study, we observed a notable reduction in the proportion of forest-dwelling species, specially those associated with streams (B. boans, B. wavrini), or breeding habitat specialists (L. pentadactylus uses burrows distant from streams for egg deposition and tadpole development) (Martins and Moreira 1991; Hödl 1990; Lima et al. 2012), the latter being found exclusively in rural sites.

The total number of species in all sites (29) was similar to that found in studies carried out in urban forest fragments and human-impacted sites in Brazilian Amazonia (Estupiñán and Galatti 1999; Tsuji-Nishikido and Menin 2011; Venâncio et al. 2014). However, the number was greater than that found in a pristine site of terra firme forest in Rio Preto da Eva, some $110 \mathrm{~km}$ west of our study area, where complementary methods (active, passive, diurnal and nocturnal samplings) resulted in the record of 23 species (Ilha and Dixo 2010). The difference might have been caused by the smaller sampling area and lower sampling effort by Ilha and Dixo (2010) relative to our study. The number of species in our study was smaller than that 
reported from nearby extensively sampled sites, such as Reserva Ducke, in Manaus (53 species; Lima et al. 2012). Differences in species richness between our study sites and other localities may also be associated with the use of different sampling methods, such as using both passive and active searches and low replication of the sampling locations, mainly in the rural sites of the Itacoatiara municipality. In addition, differences in local environmental characteristics may be an important factor in explaining variation in herpetofauna assemblages (Cole $e t$ al. 2013). Higher number of Hylidae and Leptodactylidae species were also reported in other studies carried out in Amazonian urban fragments (Estupinán and Galatti 1999; Tsuji-Nishikido and Menin 2011), pristine terra firme forests (Lima et al. 2012) and várzea forests (Waldez et al. 2013).

In both rural and urban sites, we found species that are associated with different Amazonian habitats such as open areas, terra firme, igapó and várzea forest and floating meadows. Open area species comprised $37 \%$ and $65 \%$ of all individuals in the rural and urban sites, respectively. In the rural sites, we found species that are typically found in terra firme forests (e.g. B. boans, O. taurinus), or commonly found in igapó and várzea forests, and floating meadows (e.g. $B$. punctata, D. walfordi, L. bolivianus) (Neckel-Oliveira and Gordo 2004; Lima et al. 2012; Waldez et al. 2013; Bönning et al. 2017). The presence of several open area species in rural sites is not surprising, due to the disturbance caused by the agricultural processes and livestock raising. In urban sites, we recorded species otherwise common in floating meadows in várzea habitats. The presence of these species in the urban sites may be associated with (a) habitat similarity: both floating meadows and urban sites are "open areas" allowing typical species originally adapted to floating meadows colonize the urban sites; (b) the presence of water bodies in the urban sites, allowing the reproduction of these species; and (c) the proximity of the urban sites to várzea forests.

Species composition based on species abundance (quantitative data) differed significantly between urban and rural sites and, despite the greater diversity in rural sites, there was no significant difference in qualitative data. Additionally, all species recorded in urban sites were also found in rural sites, explaining the lack of significant difference in species composition based on qualitative data. Five species reported in both urban and rural sites showed higher abundance in the urban sites. Deforestation could allow open-area specialists to expand their spatial distribution, resulting in high dominance values, as observed for $R$. major in the urban study sites. This could occur due to the resilience of some anuran species to urbanization (Oda et al. 2017), replacing forest-dwelling species. The high number of rare and accessory species and the low number of constant species in both rural and urban sites supports the hypothesis that assemblages in tropical regions have few common species and many rare species (e.g. Odum 2001). As rarefaction curves did not reach an asymptote in rural sites, additional sampling effort could add new species, which is not expected in urban sites, considering the asymptotic tendency in both sampled- and individual-based rarefaction curves.

\section{CONCLUSIONS}

Our rapid sampling of several urban and rural sites in the Itacoatiara municipality, in the central Amazon, indicated that anuran assemblages in urban sites are depauperate due to the absence of many species associated with pristine terra firme, igapó or várzea forests, probably caused by simplification and loss of the natural habitat, leading to selective species extinction. Decreased habitat quality and habitat loss in urban landscapes are the main factors threatening amphibian diversity (Hamer and McDonnell 2008). According to the recommendations of the Brazilian Amphibian Conservation Action Plan (BACAP) (Verdade et al. 2012), assessments of the effects of these factors on amphibians, specially on endemic species, should be a key priority for future mapping and research efforts. Therefore, conservation measures for anurans in Itacoatiara should consider habitat mosaics, including both pristine terra firme, várzea and igapó forest and floating meadows. The persistence of anuran populations in urban landscapes will depend on the preservation of vegetation and breeding habitats such as ponds and streams.

\section{ACKNOWLEDGMENTS}

We thank the Fundaçấo de Amparo à Pesquisa do Estado do Amazonas (FAPEAM \# PIB-B 0031/2012) for granting an undergraduate fellowship to RFBF, and the Conselho Nacional de Desenvolvimento Científico e Tecnológico (CNPq) for the Research Productivity grant to MM. We are also grateful to our colleagues of the Grupo de Pesquisa em Biologia e Produção de Organismos Aquáticos Amazônicos for the assistance with fieldwork, to the Instituto Chico Mendes de Conservaçáo da Biodiversidade (ICMBio) for granting a collection permit, and Sérgio H. Borges, Pedro A. C. L. Pequeno and Afonso J. C. G. Pereira for assistance with the multivariate analysis. Additional thanks are given to Maria Isabel da Silva and Adrian Barnett for English-language editing; Claudia Keller, Paulo Bobrowiec and the anonymous referees for suggestions during the reviewing process. Thanks to Cynthia P. A. Prado for the suggestions at the beginning of this work.

\section{REFERENCES}

Avila-Pires, T.C.S.; Hoogmoed, M.S.; Vitt, L.J. 2007. Herpetofauna da Amazônia. In: Nascimento, L.B.; Oliveira, M.E.(Eds). Herpetologia no Brasil II. Sociedade Brasileira de Herpetologia, Belo Horizonte, p.3-43.

Beebee, T.J.C.; Griffiths, R.A. 2005. The amphibian decline crisis: A watershed for conservation biology? Biological Conservation, 125: 271-285. 
Bernarde, P.S.; Macedo, L.C. 2008. Impacto do desmatamento e formação de pastagens sobre a anurofauna de serapilheira em Rondônia. Iheringia, Série Zoologia, 98: 454-459.

Bitar, Y.O.C.; Juen, L.; Pinheiro, L.C.; Santos-Costa, M.C. 2015. Anuran beta diversity in a mosaic anthropogenic landscape in transitional Amazon. Journal of Herpetology, 49: 75-82.

Böning, P.; Wolf, S.; Upton, K.; Menin, M.; Venegas, P.J.; Lötters, S. 2017. Amphibian diversity and its turnover in floating meadows along the Amazon River. Salamandra, 53: 379-388.

Cole, C.J.; Townsend, C.R.; Reynolds, R.P.; MacCulloch, R.D.; Lathrop, A. 2013. Amphibians and reptiles of Guyana, South America: illustrated keys, annotated species accounts, and a biogeographic synopsis. Proceedings of the Biological Society of Washington, 125: 317-578.

Colwell, R.K. 2013. EstimateS: Statistical estimation of species richness and shared species from samples. Version 9.1.0. (http:// viceroy.eeb.uconn.edu/estimates/). Accessed on 08/05/2014.

Colwell, R.K.; Chao, A.; Gotelli, N.J.; Lin, S-Y.; Mao, C.X.; Chazdon, R.L.; Longino, J.T. 2012. Models and estimators linking individual-based and sample-based rarefaction, extrapolation and comparison of assemblages. Journal of Plant Ecology, 5: 3-21.

Cushman, S.A. 2006. Effects of habitat loss and fragmentation on amphibians: A review and prospectus. Biological Conservation, 128: 231-240.

Dajoz, R. 1973. Ecologia Geral. 2nd ed. Ed. Vozes Ltda and EDUSP, São Paulo, 480p.

Delis, P.R.; Mushinsky, H.R.; McCoy, E.D. 1996. Decline of some west-central Florida anuran populations in response to habitat degradation. Biodiversity and Conservation, 5: 1579-1595.

Duellman, W.E. 2005. Cusco Amazónico: the lives of amphibians and reptiles in an Amazonia rainforest. Cornell University Press, Ithaca, USA, 488p.

Estupiñán, R.A.; Galatti, U. 1999. La fauna anura em areas con diferentes grados de intervención antrópica de la Amazonia Oriental Brasileña. Revista de La Academia Colombiana de Ciências Exactas Físicas y Naturales, 23: 275-286.

Fahrig, L. 2003. Effects of habitat fragmentation on biodiversity. Annual Review of Ecology, Evolution, and Systematics, 34: 487-515.

Fearnside, P.M. 2005. Deforestation in Brazilian Amazonia: history, rates and consequences. Conservation Biology, 19: 680-688.

Frost, D.R. 2018. Amphibian Species of the World: an Online Reference. Version 6.0. American Museum of Natural History, New York, USA. (http://research.amnh.org/herpetology/ amphibia/index.html). Accessed on 09/07/2018.

Funk, W.C.; Caminer, M.; Ron, S.R. 2012. High levels of cryptic species diversity uncovered in Amazonia frogs. Proceedings of the Royal Society of London B, 279: 1806-1814.

Gotelli, N.J.; Colwell, RK. 2001. Quantifying biodiversity: procedures and pitfalls in the measurement and comparison of species richness. Ecology Letters, 4: 379-391.

Hamer, A.J.; McDonnell, M.J. 2008. Amphibian ecology and conservation in the urbanizing world: a review. Biological Conservation, 141: 2432-2449.

Hammer, O.; Harper, D.A.T.; Ryan, P.D. 2001. PAST: Paleontological Statistics Software Package for Education and Data Analysis. Palaeontologia Electronica, 4: 1-9.
Hess, L.L.; Melack, J.M.; Novo, E.M.L.M.; Barbosa, C.C.F.; Gastil, M. 2003. Dual-season mapping of wetland inundation and vegetation for the central Amazon basin. Remote Sensing of Environment, 87: 404-428.

Hödl, W. 1990. Reproductive diversity in Amazonian lowland frogs. In: Hanke, W. (Ed.). Biology and Physiology of the Amphibians. Gustav Fisher Verlag, Stuttgart and New York, p.41-60.

Hoogmoed, M.S.; Galatti, U. 2017. Censo da Biodiversidade da Amazônia Brasileira - MPEG: Anura. (http://www.museugoeldi.br/censo/). Accessed on 09/07/2017.

Hu, W.; Zhang, Q.; Tian, T.; Li, D.; Cheng, G.; Um, J., et al. 2015. Relative roles of deterministic and stochastic processes in driving the vertical distribution of bacterial communities in a Permafrost core from the Qinghai-Tibet Plateau, China. PLoS ONE, 10: e0145747.

Ilha, P.; Dixo M. 2010. Anurans and lizards, Rio Preto da Eva, Amazonas, Brazil. Check List, 6: 17-21.

Junk, W.J. 2000. Neotropical floodplains: a continental-wide view. In: Junk, W.J.; Ohly, J.; Piedade, M.T.F.; Soares, M.G.M. (Eds.). The Central Amazon floodplain: actual use and options for sustainable management. Backhuys Publishers, Leiden, p.5-24.

Knispel, S.R.; Barros, F.B. 2009. Anfíbios anuros da regiâo urbana de Altamira (Amazônia Oriental), Pará, Brasil. Biotemas, 22: 191-194.

Krebs, C.J. 1999. Ecological Methodology. 2nd. ed. Addison-Wesley Educational Publishers, Menlo Park, 624p.

Lewinsohn, T. M.; Prado, P.I. 2005. How many species are there in Brazil? Conservation Biology, 19: 619-624.

Lima, A.P.; Magnusson, W.E.; Menin, M.; Erdtmann, L.K.; Rodrigues, D.J.; Keller, C.; Hödl, W. 2012. Guia de Sapos da Reserva Adolpho Ducke, Amazônia Central/ Guide to the Frogs of the Reserva Adolpho Ducke, Central Amazonia. 2nd. ed. Editora INPA, Manaus, 187p.

Marques Filho, A.O.; Ribeiro, M.N.G.; Santos, H.M.; Santos, J.M. 1981. Estudos climatológicos da Reserva Florestal Ducke Manaus - AM. IV. Precipitação. Acta Amazonica, 11:759-768.

Martins, M.; Moreira, G. 1991. The nest and the tadpole of Hyla wavrini, Parker (Amphibia, Anura). Memórias do Instituto Butantan, 53: 197-204.

McDonald, R.I.; Kareiva, P.; Forman, R.T.T. 2008. The implications of current and future urbanization for global protected areas and biodiversity conservation. Biological Conservation, 141: 1695-1703.

McKinney, M.L. 2002. Urbanization, biodiversity, and conservation. BioScience, 52: 883-890.

MMA. 2014. Ministério do Meio Ambiente, Portaria No. 444 de 17 de dezembro de 2014. Lista Nacional Oficial de Espécies da Fauna Ameaçadas de Extinção. Diário Oficial da União, Seção 1, 245: 121-126.

Navas, C.A.; Otani, L. 2007. Physiology, environmental change, and anuran conservation. Phyllomedusa, 6: 83-103.

Neckel-Oliveria, S.; Gordo, M. 2004. Anfíbios, lagartos e serpentes do Parque Nacional do Jaú. In: Borges, S.H.; Iwanaga, S.; Durigan, C.C.; Pinheiro, M.R. (Eds.). Janelas para a biodiversidade no Parque Nacional do Jaú - uma estratégia para 
o estudo da biodiversidade na Amazônia. Fundação Vitória Amazônica, Manaus, p.161-176.

Oda, F.H.; Gonçalves, S.; Oda, T.M.; Tschope, L.C.R.; Briso, A.L.F.; Oliveira, M.R.F.; Takemoto, R.M.; Vasconcelos, T.S. 2017. Influence of vegetation heterogeneity and landscape characteristics on anuran species composition in aquatic habitats along an urban-rural gradient in southeastern Brazil. Zoology and Ecology, 27: 235-244.

Odum, E.P. 2001. Fundamentos de Ecologia. Fundação Calouste Gulbenkian, Lisbon, 927p.

Pantoja, D.L.; Fraga, R. de. 2012. Herpetofauna of the Reserva Extrativista do Rio Gregório, Juruá Basin, southwest Amazonia, Brazil. Check List, 8: 360-374.

Peel, M.C.; Finlayson, B.L.; McMahon, T.A. 2007. Updated world map of the Köppen-Geiger climate classification. Hydrology and Earth System Sciences Discussions, 4: 439-473.

Pillsbury, F.C.; Miller, J.R. 2008. Habitat and landscape characteristics underlying anuran community structure along an urban-rural gradient. Ecological Applications, 18: 1107-1118.

Rodríguez, L.O.; Duellman, W.E. 1994. Guide to the frogs of the Iquitos region, Amazonian Peru. University of Kansas, Special Publications, 22: 1-80 + plates 1-12.

Scott Jr., N.J. 1994. Complete species inventories. In: Heyer, W.R.; Donnelly, M.A.; McDiarmid, R.W.; Hayek, L.A.C.; Foster, M.S. (Eds). Measuring and monitoring biological diversity: standard methods for Amphibians. Smithsonian Institution Press, Washington, p.78-84.

Segalla, M.V.; Caramaschi, U.; Cruz, C.A.G.; Grant, T.; Haddad, C.F.B.; Garcia, P.C.A.; Berneck, B.V.M.; Langone, J.A. 2016. Brazilian amphibians: List of species. Herpetologia Brasileira, 5: 34-46.

SEPLANCTI. 2015. Secretaria de Estado de Planejamento, Desenvolvimento, Ciência, Tecnologia e Inovação. (http://www. seplancti.am.gov.br/wp-content/uploads/2017/02/Perfil-daRegiao-Metropolitana-da-Manaus.pdf). Accessed on 23/08/2018.

Silva, F.C.; Silva, M.O. 2010. Distribuição espacial e temporal de anuros em dois ambientes: floresta ciliar e pastagem no Município de Urupá, Rondônia. Revista Cientifica da Faculdade de Educação e Meio Ambiente, 1: 65-83.

Silvano, D.L.; Segalla, M.V. 2005. Conservação de anfíbios no Brasil. Megadiversidade, 1: 79-86.

Stuart, S.; Hoffmann, M.; Chanson, J.; Cox, N.; Berridge, R.; Ramani, P.; Young, B. 2008. Threatened Amphibians of the World. Lynx Edicions, Barcelona; IUCN, Gland; Conservation International, Arlington, 134p.

Tocher, M.D. 1998. Diferenças na composição de espécies de sapos entre três tipos de floresta e campo de pastagem na Amazônia Central. In: Gascon, C; Montinho, P. (Eds). Floresta Amazônica: Dinâmica, Regeneraçâo e Manejo. Editora INPA, Manaus, p.219-232.

Tocher, M.D.; Gascon, C.; Meyer, J. 2001. Community composition and breeding success of Amazonian frogs in continuous forest and matrix habitat aquatic sites. In: Bierregaard Jr., R.O.; Gascon, C.; Lovejoy, T.E.; Mesquita, R.C.G. (Eds.). Lesson form
Amazonia: the ecology and conservation of a fragmented forest. Yale University Press, New Haven, USA, p.235-247.

Tsuji-Nishikido, B.M.; Menin, M. 2011. Distribution of frogs in riparian areas of an urban forest fragment in Central Amazonia. Biota Neotropica, 11: 63-70.

Venâncio, N.M.; Lima, A.P.; Souza, M.B.; Magnusson, W.E. 2014. Between-year consistency of anuran assemblages in temporary ponds in a deforested areas in Western Amazonia. Herpetological Journal, 24: 155-160.

Verdade, V.K.; Valdujo, P.H.; Carnaval, A.C.; Schiesari, L.; Toledo, L.F.; Mott, T.; et al. 2012. A leap further: the Brazilian Amphibian Conservation Action Plan. Alytes, 29: 27-42.

Waldez, F.; Menin, M.; Vogt, R.C. 2013. Diversidade de anfíbios e répteis Squamata na região do baixo rio Purus, Amazônia Central, Brasil. Biota Neotropica, 13: 300-316.

RECEIVED: $24 / 01 / 2018$

ACCEPTED: $24 / 10 / 2018$

ASSOCIATE EDITOR: Paulo Bobrowiec

\section{SUPPLEMENTARY MATERIAL}

(only avaliable in the electronic version)

MENIN et al. Anuran diversity in urban and rural zones of the Itacoatiara municipality, central Amazonia, Brazil

Appendix S1. Voucher of anuran specimens collected in Itacoatiara municipality, Amazonas State, Brazil.

Rhinella major (CZPB-AA 621), Rhinella marina (CZPBAA 657, 659), Boana boans (CZPB-AA 636), Boana aff. cinerascens (CZPB-AA 642, 643), Boana cf. fasciata (CZPBAA 645), Boana geographica (CZPB-AA 644, 648, 655), Boana lanciformis (CZPB-AA 610, 611, 649, 650), Boana punctata (CZPB-AA 620, 654), Boana raniceps (CZPB-AA 623, 624, 625), Boana wavrini (CZPB-AA 646), Dendropsophus leucophyllatus (CZPB-AA 622), Dendropsophus rossalleni (CZPB-AA 615, 616), Dendropsophus walfordi (CZPB-AA 656, 658), Lysapsus bolivianus (CZPB-AA 651), Osteocephalus taurinus (CZPB-AA 647), Scinax garbei (CZPB-AA 299), Scinax ruber (CZPB-AA 638), Sphaenorhynchus dorisae (CZPB-AA 627, 629), Trachycephalus typhonius (CZPB-AA 612, 613, 614, 626), Adenomera hylaedactyla (CZPB-AA 631), Leptodactylus fuscus (CZPB-AA 634, 635), Leptodactylus longirostris (CZPB-AA 652, 653), Leptodactylus macrosternum (CZPB-AA 637), Leptodactylus pentadactylus (CZPB-AA 641), Leptodactylus petersii (CZPB-AA 401, 402, 639, 640), Leptodactylus podicipinus (CZPB-AA 617, 618, 619), Elachistocleis helianneae (CZPB-AA 632, 633), Pipa pipa (CZPB-AA 628, 630). 